\title{
Sejarah, Penerapan, dan Analisis Resiko dari Neural Network: Sebuah Tinjauan Pustaka
}

\author{
Cristina ${ }^{*}$, Ade Kurniawan ${ }^{2}$ \\ 1,2 Jurusan Teknik Informatika, Universitas Universal \\ ${ }^{1,2}$ Kompleks Maha Vihara Duta Maitreya, Sungai Panas, Batam 29456, Kepulauan Riau - Indonesia \\ email: ${ }^{1}$ cristinashuw@gmail.com, ${ }^{2}$ adekurniawanrusdy@ gmail.com
}

Received: 28 Maret 2018; Revised:10 Mei 2018; Accepted: 13 Mei 2018
Copyright (C2018 Politeknik Harapan Bersama Tegal. All rights reserved

\begin{abstract}
A Neural network is a form of artificial intelligence that has the ability to learn, grow, and adapt in a dynamic environment. Neural network began since 1890 because a great American psychologist named William James created the book "Principles of Psycology". James was the first one publish a number of facts related to the structure and function of the brain. The history of neural network development is divided into 4 epochs, the Camelot era, the Depression, the Renaissance, and the Neoconnectiosm era. Neural networks used today are not 100 percent accurate. However, neural networks are still used because of better performance than alternative computing models. The use of neural network consists of pattern recognition, signal analysis, robotics, and expert systems. For risk analysis of the neural network, it is first performed using hazards and operability studies (HAZOPS). Determining the neural network requirements in a good way will help in determining its contribution to system hazards and validating the control or mitigation of any hazards. After completion of the first stage at HAZOPS and the second stage determines the requirements, the next stage is designing. Neural network underwent repeated design-train-test development. At the design stage, the hazard analysis should consider the design aspects of the development, which include neural network architecture, size, intended use, and so on. It will be continued at the implementation stage, test phase, installation and inspection phase, operation phase, and ends at the maintenance stage.
\end{abstract}

Abstrak - Neural network adalah bentuk kecerdasan buatan yang memiliki kemampuan belajar, tumbuh, dan beradaptasi dalam lingkungan yang dinamis. Neural network mulai ada sejak tahun 1890 karena seorang psikolog Amerika terbesar yang bernama William James menciptakan buku "Principles of Psycology". James adalah orang pertama menerbitkan sejumlah fakta yang berkaitan dengan struktur dan fungsi otak. Sejarah perkembangan neural network dibagi menjadi 4 zaman, yaitu zaman Camelot, zaman Depression, zaman Renaissance, dan zaman Neoconnectiosm. Neural network yang digunakan sekarang tidak seratus persen akurat. Walaupun demikian, neural network masih digunakan karena kinerja yang lebih baik daripada model komputasi alternatif. Penggunaan neural network terdiri dari pattern recognition, signal analysis, robotics, dan expert systems. Untuk analisis resiko terhadap neural network, pertama-tama dilakukan dengan menggunakan hazards and operability studies(HAZOPS). Menentukan persyaratan neural network dengan cara yang baik akan membantu dalam

*) Corresponding author: Cristina

Email: cristinashuw@gmail.com menentukan kontribusinya terhadap bahaya sistem dan memvalidasi kontrol atau mitigasi setiap bahaya. Setelah selesai tahap pertama pada $H A Z O P S$ dan tahap kedua menentukan persyaratannya, tahap selanjutnya yaitu mendesain. Neural network menjalani pengembangan design-train-test yang berulang berkali-kali. Pada tahap desain, analisis bahaya harus memperhatikan aspek desain dari pengembangan, yang mencakup arsitektur neural network, ukuran, penggunaan yang dimaksudkan, dan lain-lain. Kemudian akan dilanjutkan pada tahap implementasi, tahap uji coba, tahap instalasi dan pemeriksaan, tahap pengoperasian, dan berakhir pada tahap maintenance.

Kata Kunci - Neural Network, Analisis Resiko, Analisis Bahaya, Tinjauan Pustaka

\section{PENDAHULUAN}

Sejak awal, kecerdasan buatan telah difokuskan pada perbaikan di bidang ilmu komputer yang luas, dan telah memberikan kontribusi yang cukup besar untuk penelitian di berbagai bidang ilmiah dan teknis. Karya ini terutama mempertimbangkan penggunaan teknik pemodelan komputasi di bidang kecerdasan buatan [1].

Neural network merupakan salah satu bagian dari kecerdasan buatan yang memiliki kemampuan untuk belajar, tumbuh, dan beradaptasi dalam lingkungan yang dinamis. Neural network yaitu metode pembelajaran yang biasa digunakan untuk permasalahan diskrit, real ataupun vektor dan juga pemodelan sistem saraf manusia dalam melaksanakan tugas. Proses belajar neural network yaitu dirangsang oleh lingkungan, kemudian mengubah dirinya sebagai hasil rangsangan ini, dan memberikan respon dengan cara yang baru kepada lingkungan.

Proses pembelajaran neural network terdiri dari Supervised Learning dan Unsupervised Learning. Supervised Learning adalah proses belajar yang perlu pengetahuan lingkungan yang akan direpresentasikan sebagai input dan output. Model neural network yang termasuk Supervised Learning adalah dengan arsitektur MultiLayer Perceptron (MLP) yang kebanyakan digunakan untuk pendidikan.

Sejarah yang ditinjau pada paper ini fokusnya adalah pada orang-orang yang telah berkontribusi terhadap neural network dan bukan hanya pada teori atau teknologi. Pada paper ini, telah ditinjau kontribusi sejumlah individu, dan menghubungkannya dengan bagaimana sebuah neural 
network diterapkan hingga hari ini. Alat neural network adalah alat analisis, yang dimodelkan dari struktur otak manusia. Alat ini mensimulasikan struktur komputasional paralel yang saling berhubungan dengan banyak elemen pemrosesan individual yang relatif sederhana.

Sejarah perkembangan neural network dibagi menjadi empat segmen atau zaman. Kita mulai melihat sejarah neural network pada Era Camelot dengan seorang psikolog Amerika terbesar yang pernah ada, yaitu William James. Era Camelot kemudian berakhir pada tahun 1969, dengan penerbitan buku dari Minsky dan Papert tentang perceptron. Zaman selanjutnya yaitu zaman Depression yang berlangsung dari tahun 1969 hingga 1982, ketika paper Hopfield mengenai neural networks and physical systems dipublikasikan. Zaman ketiga yaitu zaman Renaissance yang dimulai ketika paper Hopfield dipublikasikan dan berakhir dengan dipublikasikannya paper dari Rumelhart dan McClelland pada tahun 1986 [2]. Zaman keempat, yang bernama zaman Neoconnectionism dimulai setelah artikel dari Cowan dan Sharp tentang neural nets and artificial intelligence di revisi, berlangsung dari tahun 1987 hingga sekarang.

Dengan kemampuan untuk belajar dan beradaptasi, neural network mengenalkan solusi dan pendekatan potensial baru ke beberapa masalah yang lebih menantang yang dihadapi Amerika Serikat karena mengejar visi penjelajahan luar angkasa. Misalnya, salah satu bidang masalah potensial yang ada pada kontrol kendaraan udara dan darat. Agar sukses dalam misi ke Mars dan Bulan, sistem adaptif yang cerdas, seperti neural network, diperlukan untuk membantu sebuah kapal dalam mengakomodasi lingkungan yang senantiasa berubah. Kendala utama untuk menerapkan sistem yang sangat kompleks adalah verifikasi dan validasi dari sistem ini.

Kebutuhan tersebut diakui oleh organisasi seperti NASA, bahwa fungsi pendukung verifikasi dan validasi harus diajukan untuk sistem neural network demi mendapatkan penerimaan yang diperlukan dalam domain masalah masingmasing. Sebagai fasilitas yang bertanggung jawab untuk memastikan keamanan perangkat lunak, kehandalan, dan kualitas program dan misi, NASA Independent Verification and Validation $(I V \& V)$ akan semakin ditantang untuk mengesahkan dan mengevaluasi sistem perangkat lunak yang berisi teknologi neural network. NASA IV \& V Facility telah mengenali kebutuhan dan pentingnya teknologi neural network karena hal ini menjadi lebih layak untuk digunakan dalam aplikasi antariksa masa depan. Untuk mengatasi kebutuhan ini, NASA IV\&V Facility mensponsori Institute for Scientific Research, Inc. (ISR) di bawah Research Grant NAGS-12069 melalui Pusat Penerbangan Antariksa Goddard $N A S A$, untuk meneliti dan mengembangkan metodologi untuk verifikasi dan validasi neural network.

Selama penelitian tiga tahun terakhir, NASA IV \& V Facility telah memeriksa beberapa metode dan prosedur yang lebih menjanjikan untuk verifikasi dan validasi neural network dan sistem adaptif. Neural network bukan solusi sempurna, namun mampu menyebarkan metode dan prosedur untuk memverifikasi dan memvalidasi sistem yang sangat kompleks sehingga dapat digunakan dalam aplikasi yang kritis. Metode dan prosedur yang disajikan dipilih karena penerapannya, tingkat kematangan teknologi, kelayakan teknis, dan kegunaan dalam verifikasi dan validasi neural network.
NASA IV \& V Facility bekerja untuk berada di garis depan keamanan perangkat lunak dan jaminan untuk programprogram utama NASA. Paper ini adalah alat yang sangat baik untuk mempersiapkan NASA IV \& $V$ dan juga praktisi verifikasi \& validassi lainnya untuk memastikan sistem perangkat lunak neural network untuk misi NASA di masa depan.

Standar ini yang dimaksudkan bersifat umum dan berlaku untuk semua jenis perangkat lunak. Namun, panduan khusus untuk analisis resiko dan bahaya yang terkait dengan karakteristik khusus perangkat lunak neural network diperlukan, dan saat ini tidak tersedia.[3] dan [4] memberikan kerangka umum untuk penilaian probabilitas-probabilitas perangkat lunak. Ini juga berlaku secara umum untuk perangkat lunak, namun tidak spesifik, atau tidak berlaku dalam beberapa kasus, ke neural network. Tujuan penelitian yang diuraikan dalam paper ini adalah untuk menyediakan jalur penelitian yang disarankan untuk penilaian resiko sistem neural network.

\section{NEURAL NETWORK}

Awal bermunculnya neural network berasal dari penelitian pada otak manusia, dimana komponen dasarnya yaitu otak dan saraf, yang ditemukan pada tahun 1836. Sel saraf memiliki nukleus dan dua pelengkap yang lain yaitu dendrit dan akson. Dendrit memiliki fungsi untuk menerima impuls dari saraf lain dan diteruskan ke badan sel, sedangkan akson bertujuan untuk menghantarkan impuls yang meninggalkan badan sel dan diteruskan ke neuron lain. Sinapsis adalah jarak antara dendrit dan akson, seperti pada Gbr 1.

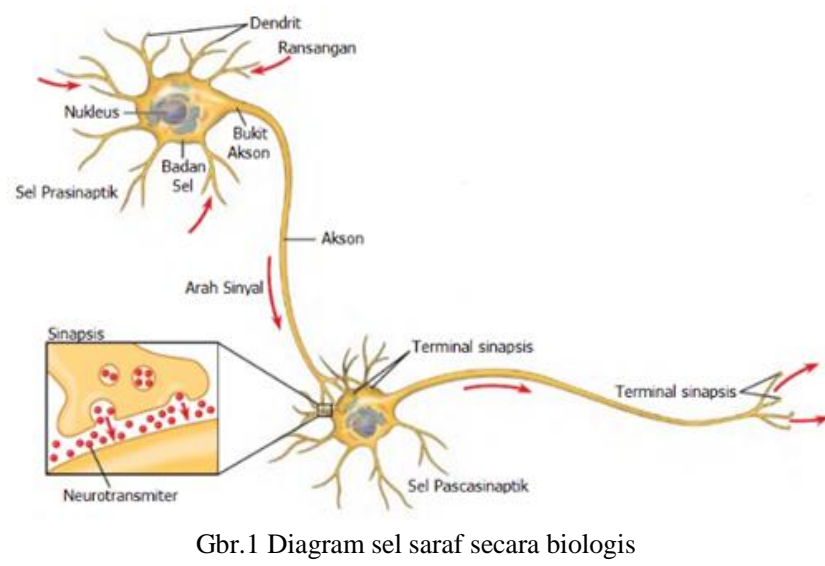

Karena adanya sebuah akson yang menghantarkan impuls dan juga adanya dendrit yang menerima impuls, maka sebuah saraf bisa menerima beberapa saraf lainnya yang kemudian akan membawa sinyal listrik dengan melintasi sinapsis. Dalam sebuah otak, semua saraf saling terhubung antar sesama saraf, bekerja sama, maka dapat disebut sebagai jaringan sel saraf. Saraf melakukan penjumlahan sinyal listrik yang tiba di dendritnya. Kemudian penjumlahan ini dibandingkan terhadap sebuah acuan untuk menentukan apakah saraf tersebut akan merangsang, yang menghasilkan satu generasi sinyal ke dendrit saraf lain. Pada akhir abad ke19, sinyal masukan ke saraf ditemukan mengalami pengecilan dalam sinapsis, yang berarti sinapsis membantu mengendalikan kekuatan sinyal listrik yang masuk ke neuron. 


\section{A. Zaman Camelot}

Sejarah perkembangan neural network dibagi menjadi empat zaman. Berawal dari zaman William James, disebut juga dengan zaman Camelot pada sekitar tahun 1890[5]. Neural network mulai terlihat pada era Camelot ketika seorang psikolog Amerika terbesar, William James yang sangat mengerti dan telah mengajarkan fisiologi ini mulai muncul. James menerbitkan "Principles of Psychology", dan versi ringkasnya, "Psychology (Briefer Course)"[5]. James adalah orang pertama yang menerbitkan sejumlah fakta yang berkaitan dengan stuktur dan fungsi otak. Penelitian dan pengembangan neural network dimulai pada tahun 1943, karena adanya karya dari W.S. McCulloch, seorang psikiater dan neuroanatomis, dan juga W. Pitts, seorang mahasiswi matematika, dari University of Chicago. Pada paper mereka yang berjudul "A Logical Calculus of the Ideas Immanent in Nervous Activity", mereka menggabungkan bidang neurofisiologi dan logika matematika. Pada tahun 1949, Donald Hebb, seorang psikolog dari McGill University di Kanada, menerbitkan sebuah postulat baru tentang pembelajaran saraf, yaitu efektifitas sinapsis untuk mentransfer sinyal antara dua neuron yang mengalami peningkatan secara berulang di sinapsis itu.

Teori ini juga dikenal sebagai "Aturan Hebb", yang menjelaskan konsep fisiologis modifikasi sinaptik, peningkatan atau penurunan respon neuron terhadap stimulus listrik. Marvin Minsky terinspirasi oleh apa yang dilakukan oleh Hebb, kemudian Minsky mengunjungi laboratorium MIT Artificial Intelligence pada tahun 1959. Pada saat masih berstatus mahasiswa Princeton tahun 1954, Minsky telah mengembangkan tesisnya pada "Theory of Neural-Analog Reinforcement Systems and Its Application to the BrainModel Problem". Buku yang berjudul Computation: Finite and Infinite Machines[6] telah memperpanjang hasil paper dari McCulloch dan Pitts yang diterbitkan tahun 1943 dengan menjelaskan konteks dari teori otomata dan teori komputasi. Pada saat yang bersamaan, Frank Rosenblatt diperkenalkan sebagai pendekatan baru untuk pengenalan pola, perceptron, yang berpuncak pada teorema konvergensi perceptron[7]. Perceptron mewakili langkah signifikan dari hasil sebelumnya di neural network karena memperkenalkan gagasan tentang pola belajar otomatis yang sering terjadi. Pada tahun yang sama, Bernard Widrow dan Marcian Hoff memperkenalkan algoritma kuadrat terkecil dan merumuskan ADaptive LINear Element (ADALINE)[8].

Jaringan ADALINE menggunakan bobot pada input ke neuron untuk pengklasifikasian pola dan juga mampu mengambil data kontinu daripada input biner utama yang digunakan oleh jaringan lain, termasuk perceptron. Dalam buku mereka "Perceptrons", Minsky dan Seymour Papert secara matematis mendemonstrasikan beberapa keterbatasan mendasar pada jaringan single-layer seperti perceptron. Mereka juga tidak yakin multi layer mampu mengatasinya. Oleh karena keterbatasan ini, potensi teknologi neural network menjadi turun dan menyebabkan kemunduran dana secara berkelanjutan untuk penelitian neural network yang kemudian berakhir pada tahun 1969, dengan penerbitan sebuah buku oleh Minsky dan Papert pada perceptron.

\section{B. Zaman Depression}

Zaman kedua setelah zaman Camelot adalah masa kegelapan (zaman Depression) yang berlangsung dari 1969 hingga 1982. Walaupun peminat neural network telah menurun, namun tetap ada beberapa peneliti yang masih aktif melanjutkan topik ini. Pada tahun 1970an, Self-Organizing Map (SOM) diperkenalkan oleh von der Malsburg[9]. Kemudian, bersama dengan D.J. Willshaw, dia mengembangkan asosiasi SOM dengan peta yang diurutkan secara topologis di otak[10]. Pada tahun 1980, Grossburg membangun prinsip baru pengorganisasian diri yang dikenal sebagai Adaptive Resonance Theory (ART), yang pada dasarnya melibatkan bottom-up recognition layer dan topdown generative layer. Kemudian, pada tahun 1982, Tuevo Kohonen memperkenalkan pengembangan dari SOM berdasarkan struktur lattice berdimensi satu atau dua[11].

\section{Zaman Renaissance}

Zaman ketiga, zaman Renaissance, dimulai dengan paper Hopfield dan diakhiri dengan publikasi Parallel Distributed Processing, Volume 1 and 2, oleh Rumelhart dan Mc-Clelland pada tahun 1986[2]. Pada tahun 1982, J.J Hopfield memperkenalkan penggunaan fungsi energi dengan merumuskan cara baru untuk memahami perhitungan yang dilakukan oleh jaringan dengan koneksi simetris sinaptik. Perspektif baru ini, berdasarkan prinsip energi, mengakibatkan banyak peneliti dari bidang ilmu pengetahuan lain tertarik untuk mengeksplorasi dan berkontribusi pada bidang neural network. Paper Hopfield juga merupakan yang pertama kali secara eksplisit membuat kasus untuk menyimpan informasi dalam jaringan yang stabil secara dinamis.

Pada tahun 1983, Kirkpatrick, Gelatt, dan Vecchi memperkenalkan sebuah prinsip baru untuk memecahkan masalah optimasi kombinatorial yang disebut simulated annealing, yang berakar pada mekanika statistik. Dengan pendekatan ini, Ackley, Hinton, dan Sejnowski[12] mengembangkan mesin stokastik yang dikenal sebagai mesin Boltzmann memberikan fondasi untuk menghubungkan neural network ke jaringan belief dan khususnya untuk pengembangan jaringan sigmoid belief oleh Neal.

Pada tahun 1986, D.E Rumelhart dan J.L McClellan, menciptakan dua volume dalam karya mereka Parallel Distributed Processing: Explorations in the Microstructure of Cognition[2], memperkenalkan algoritma propagasi balik, yang telah muncul sebagai algoritma pembelajaran yang paling banyak digunakan untuk melatih perceptron multilayer.

\section{Zaman Neoconnectionism}

Zaman keempat, yaitu zaman Neoconnectionism setelah Cowan dan Sharp memberi ulasan pada sebuah artikel tentang "Neural nets and artificial intelligence" yang berlangsung pada tahun 1987 hingga saat ini. Pada tahun 1988, D.S. Broomhead dan D. Lowe memperkenalkan sebuah alternatif untuk perceptron multilayer dengan jaringan feed-forward yang berlapis berdasarkan radial basis functions (RBF). Karya ini telah menghasilkan upaya signifikan untuk menghubungkan desain neural network ke area metode analisis numerik dan filter adaptif linier. Seorang siswa yang memiliki gelar Ph.D., Donald F. Specht, menggunakan 
pelepasan Adaline, yang disebut Adaptive Polynomial Threshold Element, untuk menerapkan alat diagnostik vektorcardiografi yang menggunakan metode diskriminatif polinomial[13], [14]. Dosen dan rekan-rekannya kemudian melakukan perintis kerja menggunakan algoritma adaptasi LMS untuk menganalisis sinyal elektrokardiogram dewasa dan janin[15].

\section{PENERAPAN NEURAL NETWORK}

Kebanyakan neural network yang digunakan tidak $100 \%$ akurat. Solusi neural network digunakan bukan karena solusinya sempurna tetapi karena kinerjanya lebih baik daripada model komputasi alternatif.

Persetujuan pinjaman adalah salah satu contoh di mana neural network terbukti menghasilkan hasil yang lebih baik daripada teknologi yang ada, namun data tersebut tetap tidak $100 \%$ akurat. Bank telah lama menggunakan para ahli untuk mengidentifikasi kemungkinan pengembalian pinjaman yang berhasil dari entitas peminjam. Terkadang pengetahuan ini bahkan telah berubah menjadi sistem pakar, namun lembaga pemberi pinjaman tetap mencari ketepatan yang lebih baik dalam memprediksi kredit macet. Prediksi yang akurat 90\% akan menjadi perbaikan dari proses seleksi lainnya. Kemsely[16] membahas bagaimana solusi neural network memperbaiki prediksi pinjaman yang buruk dan bagaimana perbaikan neural network telah menyebabkan adopsi mereka oleh perusahaan kartu kredit sebagai bagian dari proses penyaringan aplikasi.

Untuk memberikan validasi dan verifikasi, beberapa praktisi perlu mengenal penggunaan neural network, terdapat empat area aplikasi yang perlu ditinjau luas :

1) Pattern Recognition: meliputi penglihatan, ucapan, pengenalan karakter, serta diskriminasi sasaran dan pengakuan.

2) Signal Analysis: yang meliputi pengolahan bahasa, dan melampaui pattern recognition.

3) Robotics: yang mengintegrasikan sistem kontrol, pengenalan pola, dan analisis sinyal.

4) Expert Systems: yang meliputi analisis kompleks seperti diagnosis medis atau diagnosis sistem.

Empat area aplikasi di atas tidak teruraikan. Masingmasing memiliki kompleksitasnya, dan selalu mengacu pada masalah lainnya.

\section{A. Pengenalan pola}

Pengenalan pola (pattern recognition) mencakup bidangbidang seperti penglihatan, ucapan, dan pengenalan karakter, serta diskriminasi dan pengakuan sasaran.

Praktisi validasi \& verifikasi dapat melihat neural network yang digunakan untuk aktivitas pengenalan pola. Salah satu contohnya berasal dari bandara JFK dimana neural network digunakan untuk mendeteksi bom dengan mengenali sebuah pola dari data yang dihasilkan oleh sensor sinar gamma. Dalam hal ini neural network dilatih untuk mengidentifikasi varians kecil yang terkait dengan adanya bom.

Contoh kedua adalah neural network propagasi balik yang terlatih digunakan untuk memberikan probabilitas bahwa pasien di rumah sakit terbukti mengalami serangan jantung. Neural network dilatih pada data yang dikumpulkan dari ruang gawat darurat. Dari data ini, jaringan melihat pola untuk membantu dokter dalam mengidentifikasi serangan jantung yang sebenarnya dari alarm palsu.

\section{1) Quality Control}

Quality Control dalam manufaktur berkaitan dengan memastikan bahwa produk di jalur perakitan memenuhi spesifikasi yang diinginkan. Produk pada jalur perakitan memenuhi spesifikasi yang diinginkan. Spesifikasi ini bisa ditulis untuk menggambarkan bentuk, ukuran, warna, tekstur, dan sebagainya. Neural network dapat dilatih untuk mengenali contoh yang baik dan melalui pengenalan pola dapat mendeteksi ketika sebuah produk gagal dalam mencocokkannya dengan contoh.

Sistem pengendalian kualitas neural network tidak pernah letih dan mudah dikerahkan dan menghasilkan pengukuran yang konsisten. Sistem ini adalah kandidat yang sangat baik untuk menggantikan inspektur manusia yang sering terganggu atau kewalahan dalam melakukan pekerjaan yang sama.

\section{2) Pengenalan Karakter}

Memiliki komputer yang mampu membaca bahasa tulisan manusia dapat memperbaiki antarmuka manusia-komputer dan akan menghasilkan solusi komputasi yang lebih banyak di mana-mana. Salah satu cara yang bisa dilakukan adalah melalui sistem pengenalan karakter yang memanfaatkan teknologi neural network.

Pengenalan karakter dapat digunakan sebagai bagian dari teknologi pemindaian dokumen kertas yang dikenal sebagai optical character recognition. Dalam teknologi ini, dokumen kertas dipindai pertama, diubah menjadi beberapa bentuk terbaca komputer perantara, dan kemudian diproses oleh neural network yang mencari pola abjad untuk mengidentifikasi huruf atau angka apa yang terwakili. Sistem ini bisa sangat rumit mengingat setiap manusia memiliki gaya penulisan yang membedakan yang bisa bervariasi dari yang sangat rapi hingga sangat ceroboh.

Area lain di mana neural network dapat digunakan dalam pengenalan karakter adalah antarmuka manusia dengan komputer secara langsung seperti perangkat genggam notepad atau palm computing yang baru mulai dijual. Perangkat ini menerjemahkan tulisan yang diinput secara real-time dan juga memiliki keuntungan tambahan yaitu dapat memberikan umpan balik secara instan dimana pengguna dapat memperbaiki konversi yang tidak semestinya.

Anderson[17] mengutip beberapa contoh lagi termasuk pembaca kartu kredit dengan akurasi 98-99\%, sistem yang dapat membaca kursif, dan neural network yang telah dikembangkan untuk menafsirkan karakter bahasa Asia. Karakter ini bisa jauh lebih sulit daripada bahasa berbasis roman karena mereka menggunakan kombinasi yang jauh lebih rumit.

\section{3) Pemrosesan Bahasa}

Seperti pengenalan karakter, pemrosesan bahasa juga memiliki seperangkat pola yang biasanya dapat ditafsirkan dan dikonversi oleh sistem neural network. Alih-alih pola yang terdiri dari gambar yang mewakili karakter atau kata, bahasa terdiri dari pola fonetik yang terdiri dari huruf, suku kata, dan kata-kata.

Akhir-akhir ini, neural network ditemukan dalam sistem respon suara interaktif dimana banyak pembicara 
menggunakan subset bahasa yang kurang, yaitu angka "1" sampai "0," alfabet dan nama tempat Inggris (misalnya nama negara bagian dan kota-kota yang tepat). Aplikasi pengolah kata dapat melakukan konversi dari lawan bicara ke teks untuk memberikan aplikasi digital dikte yang sangat berguna. Salah satu harapan di balik pengembangan neural network yang mampu menerjemahkan ucapan adalah menjembatani kesenjangan antara manusia dan komputer bahkan lebih dengan menyediakan antarmuka suara ke perintah secara langsung. Dengan teknologi ini, pilot mampu mengkomunikasikan pesan ke kendaraan atau ground control mereka dengan menggambarkan perintah ke satelit robot.

\section{B. Pemrosesan Sinyal}

Aplikasi pemrosesan sinyal melakukan sesuatu untuk mentransformasikan data kemudian membuat keputusan, prediksi, dll. Sementara sistem pengenalan pola dapat melakukan tindakan terhadap data mentah tanpa transformasi.

Analisis sinyal mencakup aplikasi yang dapat mengumpulkan dan menganalisis data sensor, terkadang untuk umpan balik ke sistem atau untuk keperluan pengambilan keputusan. Kemsely[16] mengidentifikasi aplikasi pemrosesan sinyal untuk pengenalan dan klasifikasi sinyal dimana pengenalan target terjadi melalui interpretasi sinyal pantulan seperti radar. Akhir-akhir ini, neural network telah terbiasa mengenali seseorang dengan gaya berjalan mereka.

Area yang memungkinkan untuk neural network dengan pemrosesan sinyal yaitu reduksi noise. Jaringan saraf adaptif dapat mempelajari perilaku mendasar yang menggambarkan fungsi noise, dan kemudian melepaskan fungsi ini dari sinyal data.

Area aplikasi yang lain untuk neural network berkaitan dengan pemrosesan sinyal adalah kompresi data. Beberapa teknik kompresi data neural network melatih jaringan pada data mentah dengan cara yang tidak diawasi - tanpa panduan, memungkinkan jaringan untuk mengetahui cara terbaik untuk melakukan kompresi. Kumpulan data dapat mengalami pengurangan dimensi dan melalui pengelompokan data internal, kelompok data serupa dapat ditunjukkan oleh data yang lebih sedikit. Jaringan DCS dalam sistem IFCS dapat dianggap sebagai kompresi data.

Kompresi data bukan berarti tidak memiliki kekurangan. Mengurangi data sepuluh dimensi yang diatur ke tujuh dimensi dapat menghemat penyimpanan data, namun bila data didekompresi ke dimensi yang lebih tinggi, beberapa informasi akan hilang. Keuntungan menggunakan neural network adalah jika mekanisme kompresi yang mendasarinya tidak diketahui, neural network mampu menerapkan pendekatan melalui adaptasi.

Gelenbe[18] membahas penggunaan neural network untuk kompresi/dekompresi data citra yang digunakan dalam konferensi video, HDTV, dan videophones. Gelenbe[18] mengemukakan bahwa popularitas neural network pada kompresi citra terutama disebabkan oleh sifat belajar mereka. Carrato[19] memberikan contoh dimana model jaringan syaraf feed-forward mampu mencapai rasio kompresi 16:1 pada beberapa gambar.

Praktisi verifikasi dan validasi dapat melihat proyek yang menggunakan neural network di bidang pengurangan noise dan kompresi data, terutama saat mempertimbangkan bahwa misi ruang angkasa masa depan akan menggunakan beragam instrumentasi dengan ketepatan yang meningkat. NASA dapat menggunakan neural network untuk mengurangi noise data telemetri, umpan data satelit, atau transmisi yang telah menempuh jarak jauh melalui ruang dalam. Seiring ketepatannya meningkat dan ukuran data yang dikumpulkan tumbuh, teknik kompresi data neural network dapat mengimbangi beberapa masalah yang terkait.

\section{Robotika}

Robotika adalah area lain di mana praktisi verifikasi dan validasi berkemungkinan untuk melihat penggunaan teknologi neural network yang ekstensif. Robotika mengintegrasikan beberapa fungsi kompleks termasuk: sistem kontrol, pengenalan pola, dan analisis sinyal. Robotika juga menggunakan banyak teknologi sistem cerdas yang berbeda dimana bentuk perangkat lunak cerdas tertentu digunakan untuk memecahkan masalah yang sangat spesifik, namun sistem komponen diharapkan dapat bekerja sama secara keseluruhan. Neural network sering dipekerjakan karena kemampuan mereka untuk menyesuaikan diri dengan situasi baru, untuk mendapatkan dan mempertahankan pengetahuan, dan untuk menggeneralisasi di luar pelatihan awal mereka.

Di luar bidang kompleks sistem otonom, neural network dikerahkan dalam berbagai aplikasi servo-control. Ini berkisaran dari aplikasi kedirgantaraan yang canggih seperti IPCS, ke berbagai sistem pendukung mobilitas seperti sistem anti-lock breaking di mobil, hingga thermostat yang sesuai dengan kondisi lingkungan.

Neural network tidak hanya tertanam dalam banyak sistem robotika di bidang manufaktur, namun sering kali terlibat dalam area kontrol proses lainnya, misalnya, perencanaan lantai toko[20] dan diagnosis[21].

\section{1) Kendaraan Otonom}

Nama lapangan penelitian dan produksi yang menggunakan teknologi kendaraan robot adalah kendaraan otonom. Dua wilayah dalam kendaraan otonom adalah kendaraan darat robotik dan Unmanned-Aerial Vehicles (UAV).

Defense Advanced Research Projects Agency (DARPA) baru-baru ini mensponsori sebuah kompetisi robot yang disebut Grand Challenge untuk mempromosikan pengembangan teknologi kendaraan otonom. Peserta lomba harus merancang kendaraan yang bisa melintasi rute padang pasir dalam waktu kurang dari sepuluh jam, tanpa antarmuka manusia dan tanpa dikontrol, menentukan navigasi sendiri, dan menangani berbagai kondisi dan rintangan medan. Tiga belas entri diizinkan untuk bersaing dalam balapan, namun akhirnya tak satu pun dari mereka yang berhasil. Tetapi, kemungkinan penggunaan robot tidak berawak (unmannedaerial vehicles) untuk pertempuran atau pengintaian mempertahankan tujuan yang layak dan $D A R P A$ berencana untuk menjadi tuan rumah kompetisi lagi tahun depan.

NASA memiliki minat khusus dalam mengembangkan eksplorasi robot otonom karena penundaan waktu yang dapat dialami oleh ground control dimana mereka secara manual mengarahkan rover atau satelit untuk melakukan fungsi yang kompleks. Contoh kasus yang bagus dimana teknologi kendaraan robotik yang bisa digunakan adalah rover NASA Mars baru-baru ini, Spirit and Opportunity. Penundaan waktu 
planet ke planet antara Bumi dan Mars sekitar 12 menit. Situasi tunda waktu bahkan lebih buruk lagi saat misi meluas ke planet luar. Eksplorasi robot yang sangat mungkin terjadi adalah area dimana praktisi validasi \& verifikasi akan melihat neural network yang dipekerjakan.

Pengembangan $U A V$ akan menjadi salah satu area utama untuk menggunakan teknologi neural network. Terutama karena teknologi telah cukup matang sehingga perusahaan seperti Boeing sekarang siap untuk memasukkan teknologi neural network dalam pengembangan militer mereka. Keberhasilan pesawat pengintai tak berawak AS, the Globalhawk, mendorong pengembangan lebih lanjut di bidang ini.

\section{2) Kontrol Lintasan Manipulator}

Kemsely[16] menganjurkan untuk menggunakan neural network di bidang kontrol pengendali robot manipulator karena desain kinematika robot sangat sulit dan memakan waktu. Jika menggunakan neural network, maka mereka dapat menghemat waktu pengembangan yang berharga dan memecahkan masalah sendiri karena jaringan syaraf memiliki kemampuan adaptasi dan generalisasi.

Rover NASA dengan lengan instrumen diperluaskan untuk mengumpulkan data dari lingkungannya. Saat lengan itu bergerak, sebuah algoritma mengendalikan di mana ia bisa bergerak, seberapa cepat ia bisa bergerak, dan tahu bagaimana hal itu bisa bergerak pada langkah selanjutnya. Jika manipulator berubah karena tabrakan, getaran, kerusakan internal, atau bahkan kegagalan perangkat lunak, algoritma harus diubah juga untuk mengakomodasi hal ini. Mencoba memperhitungkan semua kemungkinan kegagalan bisa sangat mudah, tetapi jika tidak sepenuhnya, akan membuat perkembangan algoritma tradisional menjadi tidak mungkin. Sistem cerdas yang dapat disesuaikan dapat kembali mempelajari fungsinya sendiri.

Selain kegagalan, pertimbangan dinamis lainnya untuk pengendalian manipulator adalah menghindari hambatan. Selain mengubah sistem karena kegagalan, sistem juga harus bisa mengubah perilaku karena kondisi lingkungan atau objek yang berbeda. Sama seperti skenario kegagalan, memiliki algoritma yang dapat disesuaikan yang dapat meringankan banyak kerumitan dalam merancang algoritma kontrol yang menjelaskan setiap kemungkinan skenario.

\section{3) Intelligent Flight Control}

Kontrol penerbangan cerdas terdaftar di bawah robotika karena di sebagian besar sistem ini, neural network bertindak secara otonom untuk mengubah perilaku pesawat terbang. NASA telah mempelajari kontrol penerbangan cerdas setidaknya selama sepuluh tahun terakhir. Sistem ini dapat bervariasi dalam mengontrol neural network untuk diberikan dalam sistem.

Sistem IFCS Gen 1 menggunakan dua neural network yang berbeda. Karena ini adalah salah satu sistem kontrol penerbangan neural network yang diuji, maka batasan yang kuat ditempatkan pada neural network yang berada di dalam sistem. PTNN telah diperbaiki dan tidak beradaptasi selama sistem beroperasi. Daripada menghitung keuntungan pesawat terbang dan langsung ke kontrol permukaan, PTNN hanya menyediakan data ke bagian pengontrol penerbangan lain yang kemudian melakukan perhitungan mereka sendiri. DCS hanya menambah pengetahuan tentang PTNN. Hal itu juga terbatas pada pengaruhnya terhadap sistem.

Generasi kedua memungkinkan neural network mengendali sistem lebih dalam. Tugas komponen adaptif online adalah memperbaiki pelacakan kesalahan dan memberikan umpan balik langsung ke modul inversi dinamis. Modul inversi dinamis ini menghitung kontrol pesawat terbang dan neural network merupakan bagian yang lebih integral dari perhitungan tersebut daripada pada generasi pertama.

Generasi berikutnya mungkin akan membuat modul neural network lebih integral lagi dari sistem. Penggunaan dan kenaikan mereka yang semakin penting dalam pengendalian penerbangan cerdas terkait langsung dengan keberhasilan praktisi validasi \& verifikasi untuk mengesahkan sistem tersebut. Solusi neural network ini tidak akan pudar karena penelitian yang dilakukan oleh NASA telah menunjukkan bahwa perbaikan besar dapat dilakukan pada sistem kontrol penerbangan melalui adaptasi untuk mengakomodasi kegagalan atau kerusakan.

\section{Sistem Pakar}

Sistem Pakar pada umumnya dianggap simbolis, sistem berbasis aturan. Namun, neural network juga bisa dilatih untuk melakukan tugas ahli yaitu tugas yang selama ini dipandang membutuhkan beberapa tingkat keahlian, atau pengetahuan (knowledge-based systems). Tentu saja, cara keahlian dikodekan dalam neural network secara radikal berbeda dari seperangkat aturan yang dapat dibaca manusia. Penggunaan mereka mencakup analisis kompleks seperti yang diperlukan untuk diagnosis medis, diagnosis sistem, dan analisis keuangan.

Terkadang pengetahuan yang dibutuhkan tidak didokumentasikan secara eksplisit, atau bahkan diketahui secara sadar, namun harus diekstraksi dari data aktual. Ini adalah bidang data mining[22]. Berbeda dengan pembahasan sebelumnya tentang pengenalan pola, di mana setidaknya pola yang dikenali diketahui, data mining difokuskan untuk mengidentifikasi pola yang sebelumnya tidak dikenal.

Metode berkelompok dari teori data handling dan aplikasinya merupakan salah satu contoh upaya propagasi dari metode inductive self-organizing ke solusi masalah praktis yang kompleks[23].

\section{1) Diagnosa}

Salah satu aplikasi diagnostik tersebut adalah sistem diagnosa yang bisa mendeteksi mesin macet hanya dari noise. Kemsely[16] membahas sistem yang dikembangkan oleh Odin Corp., yang berfungsi untuk mendeteksi kesalahan pada mesin yang beroperasi di atas $10.000 \mathrm{rpm}$. Manfaatnya adalah bahwa misfires dianggap sebagai penyebab utama polusi, selain itu pendeteksian dan akomodasi misfires bisa mengurangi masalah.

Area yang paling mungkin melibatkan diagnosis yang akan dihadapi oleh praktisi validasi \& verifikasi adalah di bidang pemantauan kesehatan kendaraan cerdas. Sistem yang diharapkan beroperasi dalam waktu lama tanpa interaksi manusia memerlukan teknologi ini untuk mendeteksi kegagalan dalam sistem dan melakukan koreksi. Manfaat yang diharapkan adalah untuk satelit, eksplorasi robot jarak jauh, dan bahkan pesawat militer dan komersial yang dapat 
mendiagnosis masalah yang akan datang dan segera melaporkannya ke pilot.

Bidang lain dalam diagnosa neural network adalah pengenalan pola dalam data sensor industri medis[24]. Neural network sekarang digunakan dalam pemindaian PAP. Jaringan ini mencoba melakukan pekerjaan yang lebih baik saat membaca smear daripada yang bisa dilakukan oleh teknisi lab rata-rata. Diagnosis yang tidak terjawab di industri ini bisa menjadi masalah serius. Dalam banyak kasus, seorang profesional harus memahami pola dari noise, seperti mengidentifikasi fraktur dari sinar- $\mathrm{X}$ atau kanker dari sinar- $\mathrm{X}$ "bayangan". Neural network sangat membantu di banyak bidang profesi medis di mana data sulit dibaca, terutama bila tersedia perangkat keras yang lebih cepat.

Dalam beberapa situasi, sistem diagnosa hanya digunakan untuk menyaring false-positive daripada menjadi evaluasi awal. Ini karena sistem ini dianggap lebih terpercaya bila tidak membuat diagnosa seumur hidup atau mati. Praktisi validasi \& verifikasi mungkin menghadapi teknologi ini saat memasuki dunia deteksi tahap pertama.

\section{2) Keuangan}

Meskipun tidak mungkin praktisi validasi \& verifikasi akan melihat proyek neural network di dalam wilayah analisis keuangan, area komersial ini memang pantas mendapat pengakuan. Lembaga pemberi pinjaman memanfaatkan neural network untuk mengidentifikasi keberhasilan/ kegagalan yang diharapkan dari kemungkinan pinjaman Telemarketer juga menggunakan teknologi serupa dengan menerapkan teknik data mining ke database mereka untuk mengidentifikasi kombinasi respon positif yang lebih tinggi terhadap produk mereka. Ini termasuk mengidentifikasi rumah tangga dengan keluarga yang lebih besar, mengidentifikasi waktu yang lebih baik untuk menelepon rumah tangga, dan mengeluarkan informasi tentang kebiasaan membeli rumah tangga.

Neural network juga digunakan dalam pengambilan keputusan di pasar keuangan seperti perdagangan saham dan perdagangan mata uang. Dengan menganalisis tren saham atau mata uang tertentu, dan mempelajari perilaku item dari waktu ke waktu dan terhadap banyak variabel, seseorang dapat memperbaiki proses pengambilan keputusan untuk memilih posisi tertinggi dan terendah. Anderson[17] melaporkan bahwa Daiwa Research Institute mengembangkan sistem stok neural network yang mencetak hingga $20 \%$ lebih baik daripada rata-rata Nikkei dan dapat meningkatkan tingkat keberhasilan hingga $70-80 \%$.

\section{ANALISA RESIKO DAN BAHAYA TERHADAP NEURAL NETWORK}

Proses, aktivitas, dan tugas yang terkait dengan analisa resiko dan bahaya neural network telah dicantumkan pada Gambar 2 dan Gambar 3. Pada gambar tersebut terdapat kegiatan yang dipersyaratkan, apa yang direkomendasikan oleh para peneliti dan juga oleh dokumen panduan Ames / Dryden V \& V.

\section{a) Analisis Bahaya dan Resiko dari Neural Network}

Pertama-tama, analisis bahaya dapat dilakukan dengan menggunakan hazards and operability studies (HAZOPS). Apabila sistem neural network mampu beradaptasi selama operasi berjalan, maka beberapa potensi bahaya berikut harus diperhatikan HAZOPS:

- Jaringan saraf tidak dapat beradaptasi.

- Jaringan saraf telah beradaptasi, tetapi tidak dapat mencapai konvergensi

- Jaringan saraf menyesuaikan dan menyatu, namun menyatu dengan keluaran yang salah

- Jaringan saraf menyatu ke keadaan yang benar, namun tidak dapat melakukannya dalam waktu yang dibutuhkan.

- Jaringan saraf tumbuh di luar sumber daya sistem yang tersedia selama adaptasi

\begin{tabular}{l|l|}
\hline \multicolumn{2}{|c|}{ Activity: Test V\&V } \\
\hline $\begin{array}{l}\text { Hazard } \\
\text { Analysis } \\
\text { Tasks }\end{array}$ & $\begin{array}{l}\text { Verify that test instrumentation does not introduce new hazards. Update the } \\
\text { hazard analysis. }\end{array}$ \\
\hline $\begin{array}{l}\text { Risk } \\
\text { Analysis } \\
\text { Tasks }\end{array}$ & $\begin{array}{l}\text { Review and update risk analysis using prior task reports. Provide } \\
\text { recommendations to eliminate, reduce, or mitigate the risks. }\end{array}$ \\
\hline \multicolumn{2}{|c|}{ Activity: Installation and Checkout V\&V } \\
\hline $\begin{array}{l}\text { Hazard } \\
\text { Analysis } \\
\text { Tasks }\end{array}$ & $\begin{array}{l}\text { Verify that the installation procedures and installation environment does not } \\
\text { introduce new hazards. Update the hazard analysis. }\end{array}$ \\
\hline $\begin{array}{l}\text { Risk } \\
\text { Analysis } \\
\text { Tasks }\end{array}$ & $\begin{array}{l}\text { Review and update risk analysis using prior task reports. Provide } \\
\text { recommendations to eliminate, reduce, or mitigate the risks. }\end{array}$ \\
\hline
\end{tabular}

\begin{tabular}{|c|c|}
\hline \multicolumn{2}{|r|}{ Process: Development } \\
\hline \multicolumn{2}{|r|}{ Activity: Concept V\&V } \\
\hline $\begin{array}{l}\text { Hazard } \\
\text { Analysis } \\
\text { Tasks }\end{array}$ & $\begin{array}{l}\text { Analyze potential hazards to and from the conceptual system. The analysis } \\
\text { shall 1) identify potential system hazards; 2) assess severity of each hazard, } \\
\text { 3) assess probability of each hazard; and 4) identify mitigation strategies for } \\
\text { each hazard. }\end{array}$ \\
\hline \begin{tabular}{|l|} 
Risk \\
Analysis \\
Tasks
\end{tabular} & $\begin{array}{l}\text { Identify the technical and management risks. Provide recommendations to } \\
\text { eliminate, reduce, or mitigate the risks. }\end{array}$ \\
\hline \multicolumn{2}{|r|}{ Activity: Requirements V\&V } \\
\hline $\begin{array}{l}\text { Hazard } \\
\text { Analysis } \\
\text { Tasks }\end{array}$ & $\begin{array}{l}\text { Determine software contributions to system hazards. The hazard analysis } \\
\text { shall a) identify the sottware requirements that contribute to each system } \\
\text { hazard; and b) validate that the software addresses, controls, or mitigates each } \\
\text { hazard. }\end{array}$ \\
\hline \begin{tabular}{|l|} 
Risk \\
Analysis \\
Tasks
\end{tabular} & $\begin{array}{l}\text { Review and update risk analysis using prior task reports. Provide } \\
\text { recommendations to eliminate, reduce, or mitigate the risks. }\end{array}$ \\
\hline \multicolumn{2}{|r|}{ Activity: Design V\&V } \\
\hline $\begin{array}{l}\text { Hazard } \\
\text { Analysis } \\
\text { Tasks }\end{array}$ & $\begin{array}{l}\text { Verify that logic design and associated data elements correctly implement the } \\
\text { critical requirements and introduce no new hazards. Update the hazard } \\
\text { analysis. }\end{array}$ \\
\hline \begin{tabular}{|l|} 
Risk \\
Analysis \\
Tasks
\end{tabular} & $\begin{array}{l}\text { Review and update risk analysis using prior task reports. Provide } \\
\text { recommendations to eliminate, reduce, or mitigate the risks. }\end{array}$ \\
\hline \multicolumn{2}{|r|}{ Activity: Implementation V\&V } \\
\hline $\begin{array}{l}\text { Hazard } \\
\text { Analysis } \\
\text { Tasks }\end{array}$ & $\begin{array}{l}\text { Venfy that the implementation and associated data elements correctly } \\
\text { implement the critical requirements and introduce no new hazards. Update } \\
\text { hazard analysis. }\end{array}$ \\
\hline $\begin{array}{l}\text { Risk } \\
\text { Analysis } \\
\text { Tasks }\end{array}$ & $\begin{array}{l}\text { Review and update risk analysis using prior task reports. Provide } \\
\text { recommendations to eliminate, reduce or mitigate the risks. }\end{array}$ \\
\hline
\end{tabular}

Gambar 2. Tugas Analisis Bahaya dan Resiko (Part 1)

Identifikasi resiko teknis dan manajemen pada tingkat sistem konseptual adalah tugas yang pada dasarnya tidak akan berubah dengan menggunakan neural network ataupun tidak. Selain itu, rekomendasi untuk penghapusan resiko, pengurangan dan mitigasi akan berada pada tingkat sistem dan kotak hitam "non-view" ke dalam operasi neural network sehingga resikonya akan menghasilkan strategi yang serupa untuk sistem dengan atau tanpa neural network.

Kesimpulan harus mengindikasi secara jelas hasil-hasil yang diperoleh, kelebihan dan kekurangannya, serta kemungkinan pengembangan selanjutnya. Kesimpulan dapat berupa paragraf, namun sebaiknya berbentuk point-point dengan menggunakan numbering atau bullet. Kesimpulan 
berisi mengenai kesimpulan dari penelitian yang dilakukan serta saran untuk penelitian selanjutnya.

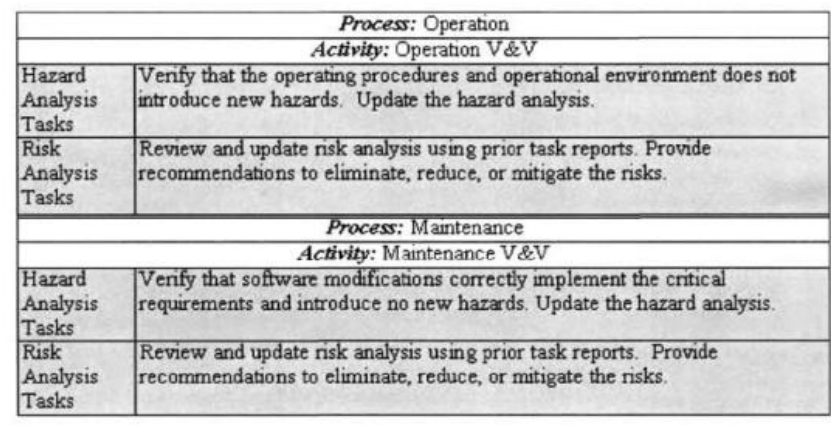

Gambar 3. Tugas Analisis Bahaya dan Resiko (Part 2)

Dalam hal menilai resiko manajemen, praktisi harus melihat keahlian anggota tim proyek dengan pengembangan neural network. Tim yang tidak pernah mengembangkan neural network akan menghadapi resiko jadwal dan anggaran. Mereka mungkin tidak memiliki cukup pengalaman untuk mengetahui bagaimana merancang neural network secara efisien, sehingga perlu menggunakan sumber daya ekstra untuk mengembangkan jaringan, mengidentifikasi cara pengujian dan memvalidasi sistem neural network yang efektif.

Dari sudut pandang resiko teknis, analisis perlu berkonsentrasi pada penggunaan solusi yang benar untuk neural network. Pertanyaan yang diperlukan untuk menyelidiki resiko teknis yaitu apakah sistem neural network merupakan solusi tepat untuk memecahkan masalah, apakah neural network harus disesuaikan secara online atau tidak, dan tipe keselamatan apa yang dibutuhkan sistem keselamatan.

\section{b) Persyaratan untuk Analisis Bahaya dan Resiko dari} Neural Network

Pada tahap persyaratan, analisis bahaya dan resiko untuk sistem yang menggunakan neural network mulai berbeda dari sistem yang menggunakan perangkat lunak konvensional. Akan ada persyaratan yang secara khusus untuk menangani komponen neural network dan persyaratan ini dapat digunakan, seperti persyaratan perangkat lunak jaringan nonneural, untuk mendukung tugas analisis bahaya dan resiko selama tahap ini. Menentukan persyaratan neural network dengan cara yang baik akan membantu dalam menentukan kontribusinya terhadap bahaya sistem dan memvalidasi kontrol atau mitigasi setiap bahaya. Model kesalahan digunakan untuk memberikan landasan bagi metode penilaian resiko seperti HAZOPS, FMEA, dan Fault Tree Analysis (FTA).

Identifikasi resiko untuk sistem neural network selama tahap persyaratan bisa lebih sulit daripada identifikasi resiko yang dilakukan untuk sistem perangkat lunak tradisional. Contoh area resiko yang dapat dipertimbangkan selama tahap ini meliputi:

1) Resiko yang dikenalkan oleh spesifikasi dan pengumpulan data pelatihan serta pengujian

Resiko dari spesifikasi data pelatihan dan pengujian untuk pengembangan neural network dapat menjadi resiko teknis ataupun manajemen. Untuk resiko manajemen, mungkin ada kekhawatiran yang terkait dengan waktu yang dibutuhkan untuk mengumpulkan kumpulan data dan kemampuan proyek untuk melacak dan mengidentifikasi kumpulan data yang telah dikumpulkan.

Resiko teknis yang terkait dengan data pelatihan adalah kurangnya kumpulan data yang cukup besar untuk memperoleh pengetahuan yang tepat. Dengan kata lain, neural network tidak akan bisa mendekati fungsi yang diinginkan dengan baik. Tim proyek mungkin perlu memikirkan cara untuk meningkatkan ukuran kumpulan data seperti test data generation.

Pendekatan dalam pengujian dan pelatihan terhadap sistem neural network secara normal mungkin akan meninggalkan ukuran data pengujian yang tidak memadai, terutama dalam kasus safety and mission-critical systems. Biasanya, seluruh kumpulan data yang tersedia dipecah menjadi $75 \%$ pelatihan dan $25 \%$ data pengujian. Batas pada set pengujian mungkin tidak mengevaluasi sistem dengan tepat. Kegiatan seperti penilaian reliabilitas dan analisis ketahanan mungkin memerlukan puluhan ribu kasus untuk pengujian. Jika proyek tidak mempersiapkan beberapa masalah ini dalam spesifikasi data pengujian, resiko yang terkait perlu didokumentasikan.

\section{2) Resiko yang dikenalkan oleh spesifikasi kinerja neural network}

Jika persyaratan kinerja neural network tidak dinyatakan dengan benar atau terlalu sulit untuk didapatkan, maka sebuah proyek akan menghabiskan waktu yang lebih lama untuk mengembangkan neural network yang memenuhi kriteria kinerja. Sehingga hasilnya akan menjadi kelewatan waktu dan anggaran yang melewati batas. Kemungkinan cara untuk mengurangi resiko ini adalah menggunakan alat pelatihan neural network yang andal, menyertakan pengembang neural network yang berpengetahuan di tim, dan menetapkan kriteria kinerja yang terdefinisi dengan baik.

\section{c) Desain untuk Analisis Bahaya dan Resiko dari Neural Network}

Pada tahap perancangan, tugas analisis bahaya meliputi verifikasi bahwa perancangan logika dan elemen data terkait menerapkan persyaratan kritis dan tidak mengenalkan bahaya baru. Tugas analisis resiko pada tahap ini termasuk memberikan rekomendasi untuk menghilangkan, mengurangi, atau mengurangi resikonya. Rincian sekarang dapat ditambahkan ke model kesalahan neural network, FMEA dan FTA yang lebih rinci dapat dilakukan. Analisis penelitian dan contoh tambahan FMEA dan FTA untuk neural network diperlukan. Bagian ini memberikan contoh FMEA untuk Intelligent Flight Control System (IFCS) generasi berikutnya (GEN2). Analisis stabilitas Lyapunov dapat digunakan untuk membuktikan konvergensi dan monitor pengaman dapat digunakan untuk mengurangi resiko yang terkait dengan penggunaan neural network dalam sistem kritis keamanan real-time. Kedua dokumen panduan Ames/Dryden memberikan rekomendasi untuk tahap desain Validasi \& Verifikasi, walaupun tidak ada rekomendasi khusus untuk analisis bahaya atau resiko.

Neural network menjalani pengembangan design-traintest yang mungkin berulang-ulang beberapa kali. Untuk tahap 
desain, analisis bahaya hanya harus memperhatikan aspek desain dari pengembangan. Ini mencakup perancangan arsitektur neural network, ukuran, penggunaan yang dimaksudkan, pengumpulan training-testing data, dan lainlain.

Bahaya yang disebabkan oleh desain neural network antara lain:

- Kumpulan data pelatihan tidak sesuai dengan tujuan yang diinginkan.

- Kumpulan data pelatihan dan tes tidak dilacak dalam manajemen konfigurasi dan tidak dijelaskan dalam dokumentasi desain.

- Kurangnya data pengujian yang memadai

- Arsitektur neural network tidak sepenuhnya ditentukan.

- Implementasi jaringan sebelum pelatihan tidak benar (jumlah awal neuron, matriks koneksi, fungsi pertumbuhan / pembelajaran, atau fungsi aktivasi mengandung kesalahan).

- Algoritma pertumbuhan/pembelajaran yang tidak tepat dipilih, sehingga menyebabkan perolehan pengetahuan yang kurang optimal.

Beberapa resiko manajemen yang dapat ditemui selama tahap perancangan mencakup dampak biaya yang terkait dengan kebutuhan untuk membeli lingkungan pengembangan neural network atau alat dan perangkat uji khusus. Ada juga resiko jadwal karena tim proyek yang kurang berpengalaman dalam mengembangkan solusi neural network.

Resiko teknis termasuk data pelatihan dan pengujian yang tidak mencukupi. Dengan data pelatihan yang tidak mencukupi, proyek mungkin tidak dapat menggeneralisasi atau mensponsori pembelajaran neural network. Dengan data pengujian yang tidak mencukupi, proyek ini mungkin kurang mampu membuktikan kebenaran, keamanan dan keandalan neural network. Data pelatihan dan pengujian harus mewakili keseluruhan data domain, bukan hanya beberapa contoh terkendala. Terutama dalam hal aplikasi safety-and missioncritical, kemampuan untuk menunjukkan kinerja algoritma neural network di seluruh domain aplikasi diperlukan untuk penerimaan sistem.

Resiko teknis lainnya muncul karena pemilihan struktur neural network yang tepat, mengingat masalah dipecahkan. Memilih algoritma neural network yang sesuai akan mempengaruhi kelayakan perancangan dan implementasi sistem. Proses seleksi tidak terdokumentasi dengan baik dalam literatur.

Proyek mungkin tergoda untuk mengabaikan praktik terbaik rekayasa perangkat lunak karena tidak mudah diaplikasikan pada neural network. Telah sering dikatakan bahwa pengembangan neural network lebih merupakan seni daripada sains. Jika tim pengembangan tidak mengambil semua tindakan pencegahan yang diperlukan seperti mengendalikan data pelatihan, desain perekaman dan prosedur pelatihan, maka ada kemungkinan hasil akhirnya, tidak peduli seberapa tepat solusi, akan menjadi hal yang tidak dapat dijelaskan dan tidak mungkin diulang harus itu menjadi perlu.

\section{d) Pelaksanaan Analisis terhadap Bahaya dan Resiko dari} Neural Network

Pada tahap implementasi, tugas analisis bahaya mencakup verifikasi bahwa implementasi dan elemen data yang terkait benar melaksanakan persyaratan kritis dan tidak mengenalkan bahaya baru. Tugas analisis resiko pada tahap ini termasuk memberikan rekomendasi untuk menghilangkan, atau mengurangi resikonya. Model penilaian resiko, seperti model kesalahan, FMEA, analisis bahaya, dan FTA, dapat diperbarui per rincian pelaksanaan. Analisis sensitivitas dan injeksi kesalahan dapat menjadi alat yang berguna untuk menguji kinerja teknik mitigasi risiko. Kedua dokumen panduan Ames / Dryden memberikan rekomendasi untuk tahap implementasi Validasi \& Verifikasi, walaupun tidak ada rekomendasi khusus untuk analisis bahaya atau resiko.

Selama tahap implementasi, analisis bahaya harus berfokus pada bahaya yang terpengaruh atau diperkenalkan melalui pembelajaran data pelatihan oleh neural network. Desain sebenarnya dari neural network ditangani pada tahap desain. Di sini, fokusnya perlu pengetahuan dan seberapa baik pengetahuan diperoleh. Beberapa contoh bahaya meliputi:

- Melalui pembelajaran dan / atau pertumbuhan, struktur neural network melebihi keterbatasan komputasi sistem.

- Neural network terlalu lama beradaptasi dengan rangsangan baru.

- Neural network tidak pernah mencapai titik stabilitas. Kinerja neural network berosilasi di sekitar metrik kriteria keberhasilan yang ditentukan namun tidak pernah mencapai metrik yang dimaksud.

- Neural network terlalu umum dan tidak dapat memberikan solusi yang sesuai untuk masalah spesifik.

- Neural network terlalu khusus dan tidak dapat memberikan solusi umum untuk masalah domain.

- Perilaku teramati neural network tidak dapat diprediksi atau berulang.

Resiko manajemen yang terkait dengan tahap implementasi adalah hilangnya waktu karena kurangnya pemahaman tentang strategi pelatihan yang efektif. Jika pembelajaran neural network tidak pernah menyatu, tim proyek mungkin menghabiskan terlalu banyak waktu untuk mencapai ukuran kinerja yang diinginkan dan tidak pernah mendekati. Resiko manajemen lainnya adalah hilangnya kontrol versi proses pelatihan neural network, sehingga proyek tidak dapat mengulang proses pelatihan atau menginspeksinya saat mencari masalah.

Resiko teknis meliputi kurangnya data pelatihan atau pengujian yang memadai, terutama untuk memenuhi kebutuhan pengujian dan penilaian reliabilitas yang ketat. Resiko teknis lain yang mungkin terjadi saat perancang neural network telah melatih neural network untuk memenuhi kriteria kinerja, namun gagal untuk menguji secara memadai neural network di seluruh profil operasional. Dalam kasus ini, jaringan mungkin tampak berkinerja benar, namun dalam situasi tertentu yang tidak diperhatikan, jaringan sebenarnya berkinerja cukup buruk.

e) Pengujian terhadap Analisis Bahaya dan Resiko dari Neural Network

Pada tahap uji coba, tugas analisis bahaya meliputi verifikasi bahwa instrumentasi uji tidak mengenalkan bahaya 
baru. Tugas analisis resiko pada tahap ini termasuk memberikan rekomendasi untuk menghilangkan, atau mengurangi resikonya. Uji injeksi kesalahan dapat digunakan untuk menguji kinerja teknik mitigasi resiko. Kesalahan untuk menyuntikkan dapat ditemukan dalam detail model kesalahan. Ini juga dapat disebut pengujian $F M E A$ dan disarankan dalam dokumen panduan Ames / Dryden.

Selama tahap pengujian, resiko dan bahaya biasanya berhubungan dengan penerimaan sistem neural network secara tidak tepat. Hal ini bisa terjadi melalui penggunaan teknik pengujian atau simulasi yang gagal memadat neural network secara memadai. Contoh lainnya termasuk:

- Gagal memeriksa data pelatihan untuk kelengkapan dan kebenaran.

- Gagal meninjau pilihan masukan (memastikan pilihan masukan benar, berdasarkan teknik yang dapat diterima seperti analisis komponen utama, dsb.).

- Gagal meninjau input preprocessing dan output postprocessing untuk kebenaran.

- Prosedur pengujian yang dijelaskan dalam rencana pengujian tidak menilai secara tepat kriteria kinerja neural network seperti stabilitas dan konvergensi.

- Untuk simulasi software-in-the-loop (SILS), kasus uji tidak secara akurat mencerminkan bagaimana komponen adaptif beraksi di dalam keseluruhan sistem.

- Untuk simulasi hardware-in-the-loop (HILS), versi perangkat keras yang hampir identik tidak secara akurat mencerminkan kinerja perangkat keras sebenarnya.

Resiko teknis yang paling signifikan selama pengujian, terutama untuk sistem neural network yang adaptif dengan tingkat integritas tinggi, merupakan kegagalan sistem yang diterima secara bencana. Resiko manajemen dapat dikaitkan dengan hilangnya keefektifan karena tidak tersedianya alat dan simulasi yang tepat dan waktu yang dibutuhkan untuk memanfaatkan alat uji dan simulasi yang tersedia.

\section{f) Instalasi dan Pemeriksaan Analisis terhadap Bahaya dan Resiko dari Neural Network}

Pada tahap instalasi dan pemeriksaan, analisis bahaya harus mempertimbangkan kontribusi terhadap bahaya sistem yang diperkenalkan dari ketidaklengkapan dan ketidakcocokan. Jika sistem neural network memerlukan lingkungan di mana untuk beroperasi, potensi bahaya adalah kurangnya penyampaian lingkungan ini dengan paket instalasi. Area lain yang mungkin kelalaian adalah kegagalan untuk mengirimkan checkcases yang akan menjalankan sistem setelah instalasi untuk memastikan pemasangan tidak menimbulkan kesalahan apa pun. Jika sistem menggunakan monitor operasional real-time, monitor juga harus menjadi bagian dari paket lengkap.

Ketidakcocokan dapat diperkenalkan bila lingkungan sasaran tidak serupa dengan lingkungan pengembangan. Antarmuka antar modul yang menyediakan input atau penerimaan output dari neural network mungkin berbeda. Atribut perangkat keras komputer seperti ukuran dan kecepatan prosesor mungkin berbeda, memperkenalkan masalah kinerja. Mungkin ada banyak benang yang berjalan di papan yang sama dengan perangkat lunak neural network, bersaing untuk mendapatkan sumber daya dan menghambat operasi jaringan.

Secara umum, resiko yang dihadapi selama tahap instalasi dan pemeriksaan didasarkan pada apakah sistem beroperasi dengan benar atau tidak. Resiko lainnya harus menjadi perhatian dalam fase ini terutama bila neural network merupakan bagian dari sistem keselamatan kritis yang berpotensi menghentikan misi atau membahayakan manusia. Dalam sistem seperti itu, insiden kecil dapat menempatkan manusia pada resiko dan meningkat menjadi pemotongan anggaran, perluasan jadwal, penundaan program dan bahkan pembatalan program

\section{g) Pekerjaan yang harus dilakukan untuk Analisis Bahaya dan Resiko dari Neural Network}

Pada tahap pengoperasian, tugas analisis bahaya mencakup verifikasi bahwa prosedur operasi dan lingkungan operasional tidak menimbulkan bahaya baru. Tugas analisis resiko selama tahap ini termasuk memberikan rekomendasi untuk menghilangkan, atau mengurangi resikonya. Sangat disarankan untuk mengevaluasi penggunaan monitor operasional, analisis stabilitas dan konvergensi, dan teknik penilaian risiko (digunakan sepanjang Siklus Hidup) sebelum sistem dalam pengembangan mencapai fase Operasi V \& V.

Dengan sistem neural network yang terus belajar dan beradaptasi selama operasi sistem, analisis bahaya lebih penting daripada perangkat lunak tradisional. Alasannya adalah bahwa hal itu sering diasumsikan dengan perangkat lunak tradisional, semua bahaya yang mungkin diidentifikasi sudah ada sebelum sistem digunakan. Namun, dengan sistem adaptif, bahaya baru dapat diperkenalkan berdasarkan data apa yang masuk ke sistem dan dengan demikian bagaimana sistem belajar. Contoh bahaya meliputi:

- Prosedur operasi tidak sesuai dengan dokumentasi pengguna atau dengan persyaratan sistem.

- Kondisi operasi berbeda dari yang dimaksudkan oleh pengembang sistem.

- Data masukan diterima dari sumber yang semula tidak dimaksudkan.

- Batas sumber daya komputasi mendekati atau melampaui (seperti yang mungkin terjadi pada neural network yang tumbuh yang menambahkan lebih banyak neuron dan koneksi dari waktu ke waktu).

- Monitor operasional berfungsi secara tidak tepat karena terlalu membatasi atau tidak cukup membatasi.

Resiko teknis yang dihadapi selama fase Operasi serupa dengan fase Installasi dan Pemeriksaan. Sistem ini tidak beroperasi atau beroperasi secara tidak benar yang berkaitan langsung dengan resiko dampak buruk terhadap jadwal dan anggaran. Penggunaan monitor operasional mungkin merupakan bagian dari strategi mitigasi resiko yang lebih luas. Jika demikian, spesifik penggunaannya dalam mitigasi harus didefinisikan dengan baik. Ini mungkin termasuk perencanaan kontinjensi saat monitor operasional menunjukkan masalah kinerja sistem.

\section{h) Maintenance Bahaya dan Resiko dari Neural Network}


TABEL I

EMPAT ZAMAN SEJARAH NEURAL NETWORK

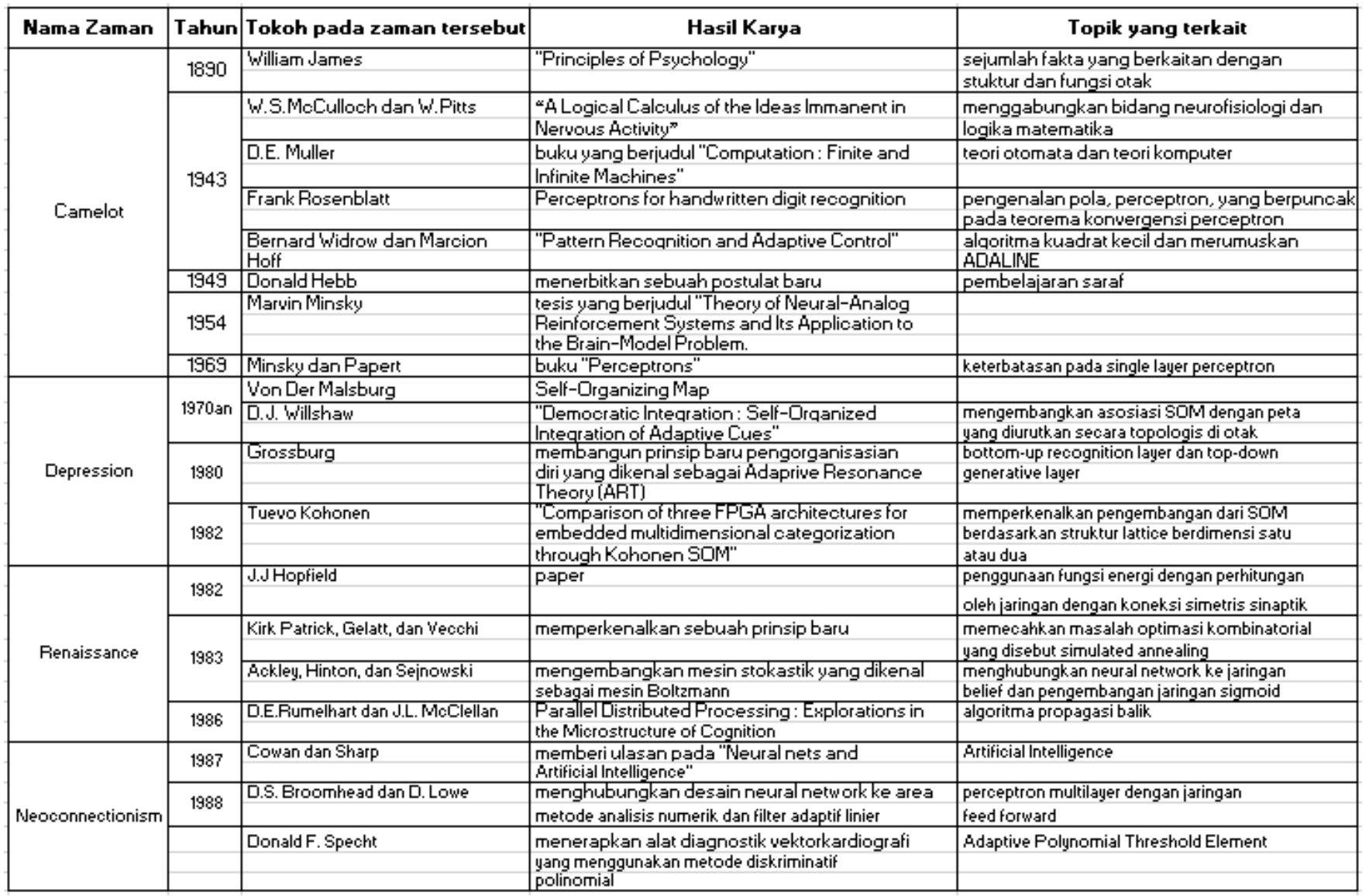

Pada tahap Maintenance, tugas-tugas analisis bahaya termasuk memverifikasi bahwa modifikasi perangkat lunak benar menerapkan persyaratan kritis dan tidak mengenalkan bahaya baru. Berdasarkan apa yang dilakukan selama perawatan, perbarui analisis bahaya dianjurkan. Misalnya, jika desain tidak berubah namun pengetahuan neural network diubah melalui pelatihan ulang, analisis bahaya harus mempertimbangkan saran yang ditemukan di bagian Analisis Implementasi, namun tidak perlu mempertimbangkan saran Desain. Demikian juga, tugas analisis resiko pada tahap ini mencakup memberikan rekomendasi untuk menghilangkan, atau mengurangi resiko berdasarkan apa yang telah dimodifikasi.

\section{KESIMPULAN}

Sejarah perkembangan neural network dibagi menjadi empat segmen atau zaman. Kita mulai melihat sejarah neural network pada Era Camelot dengan seorang psikolog Amerika terbesar yang pernah ada, yaitu William James. Era Camelot kemudian berakhir pada tahun 1969, dengan penerbitan buku dari Minsky dan Papert tentang perceptron. Zaman selanjutnya yaitu zaman Depression yang berlangsung dari tahun 1969 hingga 1982, ketika paper Hopfield mengenai neural networks and physical systems dipublikasikan. Zaman ketiga yaitu zaman Renaissance yang dimulai ketika paper Hopfield dipublikasikan dan berakhir dengan dipublikasikannya paper dari Rumelhart dan McClelland pada tahun 1986[2]. Zaman keempat, yang bernama zaman Neoconnectionism dimulai setelah artikel dari Cowan dan
Sharp tentang neural nets and artificial intelligence di revisi, berlangsung dari tahun 1987 hingga sekarang. Tujuan paper ini adalah untuk membantu praktisi validasi \& verifikasi dengan memvalidasi dari sistem jaringan yang diusulkan atau dilaksanakan. Validasi melibatkan penilaian kesesuaian solusi berbasis neural network untuk masalah yang dipecahkan.

Paper ini telah menyajikan gambaran taksonomi sistem neural network dari berbagai perspektif. Karakteristik utama dari aplikasi dan solusinya melalui neural network telah dipresentasikan. Pada tingkat tertinggi, masalah yang dibahas di sini adalah apakah arsitektur neural network bisa menjadi pilihan tepat untuk memecahkan masalah. Mengingat bahwa model neural network tertentu harus dapat memecahkan masalah, perhatian utama berikutnya adalah berfokus pada persyaratan pendukung yang harus ditangani, misalnya, arsitektur neural network tertentu.

Penggunaan neural network, terdapat empat area aplikasi yang perlu ditinjau lebih luas seperti pada tabel II. Untuk analisis resiko terhadap neural network, awalnya menggunakan hazards and operability studies(HAZOPS), yaitu menentukan persyaratan neural network dengan cara yang baik dalam menentukan kontribusinya terhadap bahaya sistem dan memvalidasi kontrol atau mitigasi setiap bahaya. Setelah itu, tahap kedua yaitu menentukan persyaratannya, dan kemudian tahap selanjutnya yaitu mendesain. Neural network menjalani pengembangan design-train-test yang berulang berkali-kali. Pada tahap desain, analisis bahaya harus memperhatikan aspek desain dari pengembangan, yang mencakup arsitektur neural network, ukuran, penggunaan 
yang dimaksudkan, dan lain-lain. Kemudian akan dilanjutkan pada tahap implementasi, tahap uji coba, tahap instalasi dan pemeriksaan, tahap pengoperasian, dan berakhir pada tahap maintenance. Tugas-tugas yang perlu dilakukan pada setiap tahap dalam menganalis resiko dan bahaya dapat dilihat pada Gbr 2 dan Gbr 3.

TABEL II

PENERAPAN NEURAL NETWORK

\begin{tabular}{|l|l|}
\hline $\begin{array}{l}\text { Pattern Recognition } \\
\text { - Penglihatan } \\
\text { - Ucapan }\end{array}$ & $\begin{array}{l}\text { Signal Analysis } \\
\text { - Pengolahan bahasa } \\
\text { - Pengenalan karakter } \\
\text { - Diskriminasi sasaran } \\
\text { - Melampaui pattern } \\
\text { recognition }\end{array}$ \\
\hline $\begin{array}{l}\text { Robotics } \\
\text { - sistem kontrol } \\
\text { - pengenalan pola } \\
\text { - analisis sinyal }\end{array}$ & $\begin{array}{l}\text { Expert Systems } \\
\text { - diagnosis medis atau } \\
\text { diagnosis sistem }\end{array}$ \\
\hline
\end{tabular}

Pedoman penilaian resiko yang spesifik untuk karakteristik khusus perangkat lunak neural network diperlukan, dan ini tidak tersedia saat ini. Kerangka kerja umum untuk penilaian probabilitas perangkat lunak telah diajukan, namun tidak spesifik, atau tidak berlaku dalam beberapa kasus, ke neural network. Pada paper ini, walaupun terbatas dalam penerapannya pada setiap sistem neural network, menunjukkan beberapa teknik penilaian resiko yang mungkin terjadi serta tempat yang berguna untuk mulai mempertimbangkan identifikasi resiko dan bahaya.

\section{DAFTAR PUSTAKA}

[1] N. Malik, Artificial Neural Networks and their Applications. 2005

[2] D. E. Rumelhart, J. L. McClelland, and the P. R. Group, "Parallel distributed processing, explanations in the micro structure of cognition, 1: Foundations," A Bradford B., p. 576, 1988.

[3] B. Li, M. Li, S. Ghose, and C. Smidts, "Integrating software into PRA,” Proc. - Int. Symp. Softw. Reliab. Eng. ISSRE, vol. 2003-Janua, pp. 457-467, 2003

[4] R. Chillarege, I. S. Bhandari, J. K. Chaar, M. J. Halliday, B. K. Ray, and D. S. Moebus, "Orthogonal Defect Classification-A Concept for
In-Process Measurements," IEEE Trans. Softw. Eng., vol. 18, no. 11, pp. 943-956, 1992.

[5] W. James, Writings 1878-1899: Psychology: Briefer Course; The Will to Believe and Other Essays in Popular Philosophy; Talks to Teachers on Psychology and to Students on Some of Life's Ideals; Selected Essays. 1992.

[6] D. E. Muller, "No Title," pp. 3-16

[7] E. Kussul, T. Baidyk, L. Kasatkina, and V. Lukovich, "Rosenblat perceptrons for handwritten digit recognition," Neural Networks, 2001. Proceedings. IJCNN '01. Int. Jt. Conf., vol. 2, pp. 1516-1520, 2001.

[8] B. Widrow, "Pattern Recognition and Adaptive Control," Appl. Ind. IEEE Trans., vol. 83, no. 74, pp. 269-277, 1964.

[9] M. Budinich, "Sorting with Self-organizing Maps," vol. 1190, no. 1992, pp. 1188-1190, 1995.

[10] J. Triesch and C. von der Malsburg, "Democratic Integration: SelfOrganized Integration of Adaptive Cues," Neural Comput., vol. 13, no. 9, pp. 2049-2074, 2001.

[11] M. A. De Abreu De Sousa and E. Del-Moral-Hernandez, "Comparison of three FPGA architectures for embedded multidimensional categorization through Kohonen's self-organizing maps," Proc. - IEEE Int. Symp. Circuits Syst., pp. 2-5, 2017.

[12] N. Brunswick, "Wp11 = 2:30,” pp. 786-791, 1988.

[13] H. H. Jasper, E. D. Adrian, J. C. Eccles, E. V. Luniel, and D. Tweel, "Vectorcardiographic Diagnosis Using the Polynomial," no. 2, pp. 9095, 1967.

[14] D. F. Specht, "Generation of Polynomial Discriminant Functions for Pattern Recognition," IEEE Trans. Electron. Comput., vol. EC-16, no. 3, pp. 308-319, 1967.

[15] B. Widrow et al., "Adaptive Noise Cancelling: Principles and Applications," Proc. IEEE, vol. 63, no. 12, pp. 1692-1716, 1975.

[16] D. M. C. Kemsely, D., T.R. Martinez, "A survey of Neural Network Research and Fielded Applications. International Journal of Neural Networks 2," vol. 2/3/4, pp. 123-133, 1992.

[17] G. Mcn. Anderson, Dave, Artificial Neural Networks Technology. Data \& Analysis Center for Software. 1992.

[18] C. C. Gelenbe, Erol, M.Sungur, Learning Random Networks for Compression of Still and Moving Images. 2004.

[19] S. Carrato, Neural Networks For Image Compression. In Gelenbe, E. (ed.) Neural Networks: Advanced and Applications 2. 1992.

[20] and S. M. Jain, A. S., "Job-Shop Scheduling Using Neural Networks."

[21] H. C. and S. H. H. Zhang, "Applications of Neural Networks in Manufacturing: a State-of-the-Art Survey,” vol. 3, pp. 705-728, 1995.

[22] J.-A. and F. L. Muller, Self-Organizing Data Mining. 2000.

[23] H. R. and A. G. I. Madala, Inductive Learning Algorithms for Complex Systems Modeling. CRC Press. 1994.

[24] P. Lisboa, "A Review of Evidence of Health Benefit from Artificial Neural Networks in Medical Intervention. Neural Networks 15,” pp. 11-39, 2002. 